\title{
STIMULATION OF GLUCOSE UTILIZATION IN $3 T 3$ ADIPOCYTES AND RAT DIAPHRAGM IN VITRO BY THE SULPHONYLUREAS, GLIMEPIRIDE AND GLIBENCLAMIDE, IS CORRELATED WITH MODULATIONS OF THE cAMP REGULATORY CASCADE
}

\author{
Günter Müller,${ }^{*}$ Susanne Wied, Eva-Marlen Wetekam, Anna Crecelius, \\ ANgelika UnKelbach and Jürgen Pünter \\ Hoechst Aktiengesellschaft Frankfurt a.M., SBU Metabolic Diseases H825, D-65926 Frankfurt am \\ Main, Germany
}

(Received 20 September 1993; accepted 26 April 1994)

\begin{abstract}
The long-term hypoglycemic activity of sulphonylurea drugs has been attributed, in part at least, to the stimulation of glucose utilization in extra-pancreatic tissues. The novel sulphonylurea, glimepiride, gives rise to a longer lasting reduction in the blood sugar level in dogs and rabbits compared to glibenclamide (Geisen K, Drug Res 38: 1120-1130, 1988). This cannot be explained adequately by elevated plasma insulin levels. This study investigated whether this prolonged hypoglycemic phase was based on the drug's abilities to stimulate glucose utilization and affect the underlying regulatory mechanisms in insulin-sensitive cells in vitro. It was found that in the absence of added insulin, glimepiride and glibenclamide $(1-50 \mu \mathrm{M})$ stimulated lipogenesis (3T3 adipocytes) and glycogenesis (isolated rat diaphragm) $\sim 4.5$ - and 2.5-fold, respectively, and reduced the isoproterenol-stimulated lipolysis (rat adipocytes) up to 40-60\%. The increased glucose utilization was correlated with a 3-4fold higher 2-deoxyglucose transport rate and amount of GLUT4 at the plasma membrane, as well as with increased activities of key metabolic enzymes (glycerol-3-phosphate acyltransferase, glycogen synthase) within the same concentration range. Furthermore, the low $K_{m}$ cAMP-specific phosphodiesterase was activated 1.8-fold, whereas the cytosolic cAMP level and protein kinase A activity ratios were significantly lowered after incubation of isoproterenol-stimulated rat adipocytes with the sulphonylureas. In many of the aspects studied the novel sulphonylurea, glimepiride, exhibited slightly lower $\mathrm{ED}_{50}$-values than glibenclamide. This study demonstrates correlations existing between druginduced stimulation of glucose transport/metabolism and cAMP degradation/protein kinase $\mathrm{A}$ inhibition as well as between the relative efficiencies of glimepiride and glibenclamide in inducing these extrapancreatic processes. Therefore, it is suggested that the stimulation of glucose utilization by sulphonylureas is mediated by a decrease of cAMP-dependent phosphorylation of GLUT4 and glucose metabolizing enzymes. The therapeutic relevance of extra-pancreatic effects of sulphonylureas, in general, and of the differences between glimepiride and glibenclamide as observed in vitro in this work, in particular, remain to be elucidated.
\end{abstract}

Key words: non-insulin-dependent diabetes mellitus; sulfonylureas; insulin signaling; glucose and lipid metabolism; protein kinase A

Sulphonylureas are widely used oral drugs for the treatment of NIDDM $\dagger$. Their initial hypoglycemic efficacy is generally explained by acute stimulation of the rate of insulin release from the pancreas. However, after long-term treatment of NIDDM patients with sulphonylurea compounds plasma insulin levels often return to pre-treatment levels

${ }^{*}$ Corresponding author. Tel. 069-305-4271; FAX 069311454.

+ Abbreviations; cAMP, cyclic AMP; DMEM Dulbecco's minimal essential medium; FCS, foetal calf serum; GLUT, glucose transporter isoforms; GPAT, glycerol-3-phosphate acyltransferase; IBMX, 3-isobutyl-1methylxanthine; NIDDM, non-insulin-dependent diabetes mellitus: PDE, cAMP-specific low $K_{m}$ phosphodiesterase; PKA, cAMP-dependent protein kinase A; LDM, low density microsomes; SDS-PAGE, sodium dodecylsulfatepolyacrylamide gel elecrophoresis; TLC, thin layer chromatography. without concomitant loss of hypoglycemic control or improved glucose tolerance $[1,2]$. This has been attributed to increased glucose disposal by peripheral tissues, as observed during euglycemic clamp studies in rats, dogs [3, 4] and NIDDM patients [5, 6]. Direct stimulation of basal and/or insulin-dependent glucose transport and metabolism in muscle and fat cells $[7,8]$ or, alternatively, an improvement in the overall metabolic situation in muscle and fat tissues due to increased insulin and reduced glucose levels, would explain increased glucose utilization after sulphonylurea administration. Experimental conditions with tightly controlled insulin and glucose concentrations will help to discriminate between these possibilities.

Therefore, cellular and cell-free assays were used to determine insulin action derived from isolated rat and cultured 3T3 adipocytes, as well as isolated rat diaphragms. The effects of the sulphonylureas, glimepiride and glibenclamide, on the rate of 
basal and insulin-stimulated glucose transport and metabolizing pathways and, in addition, on key regulatory processes of glucose metabolism, were investigated. The study was designed to allow comparison between glimepiride and glibenclamide, since it has been shown that glimepiride provokes a significantly prolonged blood sugar lowering phase compared to glibenclamide after oral or i.v. application in dogs and rabbits [9]. These observations suggested that glimepiride would exhibit stronger direct effects on the two major insulin-sensitive peripheral tissues, fat and muscle. The in vitro data from this study suggest that the molecular basis for the observed multiple stimulatory effects of glimepiride and glibenclamide on glucose transport and metabolism rely on the interference with the cAMP signalling cascade which may, thus, represent the primary target for sulphonylureas action in peripheral tissues.

\section{MATERIALS AND METHODS}

Materials. Radiochemicals were bought from Amersham-Buchler (Braunschweig, Germany); 3T3 fibroblast clone A31 was obtained from the American Type Culture Collection (CCL 163). Male Wistar rats were bred and delivered by the Hoechst Aktiengesellschaft (Tierzucht Kastengrund, Germany); semi-synthetic human insulin (I 81 0182), glimepiride (HOE 490) and glibenclamide (Hb 419) were prepared by the Pharma Synthesis Department of Hoechst Aktiengesellschaft (Frankfurt, Germany); stock solutions of glimepiride and glibenclamide were prepared on the day of use as described previously [10]. 12-[(7-nitrobenz-2-oxa1,3-diazol-4-yl)amino] dodecanoic acid was provided by Molecular Probes Inc. (Eugene, OR, U.S.A.) and dissolved in Krebs-Ringer-phosphate buffer containing $1.5 \%$ BSA and a $0.5 \mathrm{mM}$ stock solution, which was made daily. All the other materials and chemicals were obtained as described previously $[11,12]$.

Cell culture and incubation of $3 T 3$ adipocytes. This was done according to published methods [11] with modifications: cells were grown $(150$ or $35 \mathrm{~mm}$ culture plates per condition) in DMEM ( 25 or $2 \mathrm{~mL}$ per condition) containing $25 \mathrm{mM}$ glucose, $10 \%$ FCS and antibiotics. Confluent and differentiated cells $(80-90 \%$ of the cells expressed the adipocyte phenotype) were washed twice with Krebs-Ringerphosphate buffer and then incubated in the same buffer $(10$ or $1 \mathrm{~mL})$ with sulphonylurea or insulin as indicated.

Metabolic labelling of $3 T 3$ adipocytes. Plates $(150 \mathrm{~mm})$ were washed twice with methionine-free DMEM (HEPES-based) containing $10 \%$ FCS, $5.5 \mathrm{mM}$ glucose, 50 units $/ \mathrm{mL}$ penicillin, $50 \mu \mathrm{g} / \mathrm{mL}$ streptomycin sulphate and then incubated $(20 \mathrm{hr}$, $37^{\circ}$ ) with $10 \mathrm{~mL}$ of the same medium supplemented with $0.1 \mathrm{mM} \mathrm{L}-\left[{ }^{35} \mathrm{~S} / \mathrm{methionine}(0.1 \mathrm{mCi})\right.$ in the absence or presence of sulphonylurea and insulin under constant bubbling with $5 \% \quad \mathrm{CO}_{2} / 95 \% \quad \mathrm{O}_{2}$. The plates were then washed twice with ice-cold DMEM containing $10 \mathrm{mM}$ unlabelled methionine.

Preparation of $3 T 3$ adipocyte homogenate and membrane fractions. Prior to homogenization,
$150 \mathrm{~mm}$ plates were washed with DMEM as above and then once with $10 \mathrm{~mL}$ of PBS containing $1 \mathrm{mM}$ EDTA, $0.25 \mathrm{M}$ sucrose. Monolayers from four plates were scraped into $24 \mathrm{~mL}$ of ice-cold Tris-HCL/ EDTA/sucrose buffer $(10 \mathrm{mM}$ Tris- $\mathrm{HCl}, \mathrm{pH} 7.4$, $1 \mathrm{mM}$ EDTA, $0.25 \mathrm{M}$ sucrose) and immediately homogenized with 10 strokes of a motor-driven Teflon-in-glass homogenisator. PMSF (final concentration $0.2 \mathrm{mM}$ ) was added to the cell suspension prior to homogenization.

The homogenate was centrifuged $(16,000 \mathrm{~g}$, $20 \mathrm{~min})$. The pellet was resuspended in $6 \mathrm{~mL}$ of $10 \mathrm{mM}$ Tris- $\mathrm{HCl}$ ( $\mathrm{pH} 7.4), 1 \mathrm{mM}$ EDT A and applied on to a sucrose cushion $(1.12 \mathrm{M}$ sucrose in Tris- $\mathrm{HCl} /$ EDTA). After centrifugation $(100,000 \mathrm{~g}, 1 \mathrm{hr})$, the plasma membranes were removed from the top of the sucrose cushion, suspended in $25 \mathrm{~mL}$ of Tris-HCl/EDTA, $0.1 \mathrm{mM}$ PMSF, recovered by centrifugation $(30,000 \mathrm{~g}, 30 \mathrm{~min})$ and resuspended in $0.5 \mathrm{~mL}$ of Tris-HCl/EDTA, $0.1 \mathrm{mM}$ PMSF. The initial $16,000 \mathrm{~g}$ supernatant was centrifuged $(48,000 \mathrm{~g}$, $30 \mathrm{~min})$. LDM were recovered from the supernatant by centrifugation $(200,000 \mathrm{~g}, 2 \mathrm{hr})$. The pellet was suspended in $0.5 \mathrm{~mL}$ of Tris- $\mathrm{HCl} / \mathrm{EDTA}, 0.1 \mathrm{mM}$ PMSF. The membrane fractions were assayed for the activity of the plasma membrane marker enzyme, 5 '-nucleotidase [13], which was enriched 7.5-fold (plasma membranes) and 0.4-fold (LDM) towards the homogenate.

Isolation and incubation of rat adipocytes, preparation of homogenate and subcellular fractions (LDM, cytosol). These were performed according to published procedures $[12,14]$.

Preparation and incubation of rat diaphragm and preparation of homogenate. Intact hemidiaphragms were dissected from male Wistar rats as described [15] and incubated in DMEM $(10 \mathrm{~mL} /$ hemidiaphragm $)$ with constant bubbling of $\mathrm{O}_{2}: \mathrm{CO}_{2}(95: 5)$. For treatment with sulphonylureas or insulin, the hemidiaphragms were incubated $\left(37^{\circ}\right)$ in KrebsHenseleit buffer plus $5 \mathrm{mM}$ glucose for the periods indicated. For assaying glycogenesis, the hemidiaphragms were blotted on tissue, washed twice in the same buffer without glucose and then incubated with the same buffer $(3 \mathrm{~mL}$ hemidiaphragm) containing $5 \mathrm{mM}\left[\mathrm{U}^{1}{ }^{14} \mathrm{C}\right]$ glucose $(1 \mu \mathrm{Ci} / \mathrm{mL})$. The incubation was terminated after $20 \mathrm{~min}$ by transferring the diaphragms into fresh buffer containing $5 \mathrm{mM}$ glucose. For preparation of the homogenate, the diaphragms were blotted and frozen in liquid nitrogen. The frozen diaphragms (pool of four) were ground manually in a porcelain mortar and then homogenized at $0^{\circ}$ in $2 \mathrm{~mL}$ of $25 \mathrm{mM}$ Tris- $\mathrm{HCl}$ (pH 7.4), $100 \mathrm{mM}$ NaF, $5 \mathrm{mM}$ EDTA, 0.1 mM PMSF, the homogenate was then centrifuged $(10,000 \mathrm{~g}, 20 \mathrm{~min})$. The supernatant was used for the determination of radiolabelled glycogen for the glycogenesis or glycogen synthase assays (see below).

Glycogenesis. Samples of the supernatant from the diaphragm homogenate were heated $(45 \mathrm{~min}$, $\left.100^{\circ}\right)$ in $30 \% \mathrm{KOH}(1 \mathrm{~mL} / 50 \mathrm{mg}$ tissue $)$ and then adjusted to $70 \%$ ethanol. After $4 \mathrm{hr}$ at $-20^{\circ}$ the samples were centrifuged $(2000 \mathrm{~g}, 10 \mathrm{~min})$. The glycogen pellets were washed four times with $70 \%$ 
ethanol and then assayed for radioactivity by liquid scintillation counting.

Lipogenesis. This was done according to the method of Moody et al. [16]. Incorporation of D$\left[3-{ }^{3} \mathrm{H}\right]$ glucose into toluene-extractable acylglycerides was measured after incubation of 3T3 adipocytes ( $35 \mathrm{~mm}$ plate per condition) with $1 \mathrm{~mL}$ KrebsRinger-phosphate buffer (see below) in the absence or presence of sulphonylurea or insulin as indicated. Lipogenesis was initiated by the addition of $50 \mu \mathrm{L}$ of $2 \mathrm{mM}\left[{ }^{3} \mathrm{H}\right]$ glucose $(0.5 \mu \mathrm{Ci})$. After incubation $\left(90 \mathrm{~min}, 37^{\circ}\right)$ the cells were dissolved by addition of $2 \mathrm{~mL}$ toluene-based scintillation cocktail. Following $30 \mathrm{~min}$ of incubation under vigorous shaking and transfer of the mixture into scintillation vials, the radioactivity was measured in the lipid phase after phase separation had been completed (usually 10 $16 \mathrm{hr}$ ).

Glucose transport. This was measured by the uptake of 2-deoxyglucose.

3 T3 adipocytes (according to $[17,18]$ with modifications): $35 \mathrm{~mm}$ plates were incubated $\left(37^{\circ}\right)$ with $1 \mathrm{~mL}$ of Krebs-Ringer-phosphate buffer (140 $\mathrm{mM} \mathrm{NaCl}, 4.7 \mathrm{mM} \mathrm{KCl}, 1.25 \mathrm{mM} \mathrm{CaCl}_{2}, 1.25 \mathrm{mM}$ $\mathrm{MgSO}_{4}, 5 \mathrm{mM}$ sodium phosphate, $\mathrm{pH} 7.4$ ) in the absence or presence of sulphonylurea drug or insulin for the periods indicated. Uptake was initiated by the addition of $50 \mu \mathrm{L}$ of $2 \mathrm{mM} 2-\left[1-{ }^{3} \mathrm{H}\right]-$ deoxyglucose $(10 \mu \mathrm{Ci} / \mathrm{mL})$. After $5 \mathrm{~min}$ incubation in the continuous presence of sulphonylurea and/or insulin, uptake was terminated by rapid washing with an excess of ice-cold PBS containing $10 \mathrm{mM}$ glucose, $0.3 \mathrm{mM}$ phloretin. The monolayers were solubilized in $1 \mathrm{~mL}$ of $0.2 \% \mathrm{SDS}$. The radioactivity was measured by liquid scintillation counting. To correct for radioactivity non-specifically associated with the cells or entrapped in extracellular spaces, uptake was determined in parallel in the presence of the transport inhibitor cytochalasin B $(25 \mu \mathrm{M})$. These values, which accounted for up to $15 \%$ of the total radioactivity of the uninhibited plates, were subtracted to obtain specific glucose transport.

Rat diaphragm: Intact washed rat diaphragms were incubated $\left(30 \mathrm{~min}, 37^{\circ}\right)$ in HEPES-buffered saline (25 mM HEPES, $120 \mathrm{mM} \mathrm{NaCl}, 5 \mathrm{mM} \mathrm{KCl}$, $1.5 \mathrm{mM} \mathrm{CaCl}_{2}, 1 \mathrm{mM} \mathrm{MgCl}, 5 \mathrm{mM}$ glucose, $0.5 \mathrm{mM}$ sodium pyruvate, $\left.1.5 \mathrm{mM} \mathrm{KH_{2 }} \mathrm{PO}_{4}, \mathrm{pH} 7.4\right)$ under constant bubbling with $\mathrm{CO}_{2} / \mathrm{O}_{2}$. The diaphragms were then washed twice with the same buffer without glucose and further incubated $(30 \mathrm{~min})$ in $5 \mathrm{~mL}$ of glucose-free buffer in the presence of sulphonylurea or insulin. Glucose transport was initiated by addition of $50 \mu \mathrm{L}$ of $10 \mathrm{mM} 2-\left[1-{ }^{3} \mathrm{H}\right]$ deoxyglucose $(10 \mu \mathrm{Ci} /$ $\mathrm{mL})$ in the absence or presence of $25 \mu \mathrm{M}$ cytochalasin $B$ (control). After $15 \mathrm{~min}$, the diaphragms were rinsed four times with ice-cold buffer containing $10 \mathrm{mM}$ glucose and $25 \mu \mathrm{M}$ cytochalasin $\mathrm{B}$, blotted with filter paper and homogenized. Portions of the homogenate were used for protein determination. One millilitre portions of the supernatant (prepared as above) were mixed with $10 \mathrm{~mL}$ scintillation cocktail and counted for radioactivity. Specific glucose transport (dpm/mg of protein) was calculated as the difference between the diaphragm-associated radioactivity measured in the absence (total uptake) and presence of cytochalasin B (non-specific uptake).
Under these experimental conditions transport was linear for $30 \mathrm{~min}$.

Glycogen synthase. This was assayed as described previously [19], with the following modifications. After addition of $10 \mu \mathrm{L}$ of diaphragm homogenate

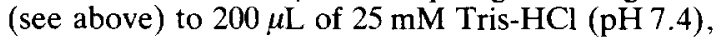
$50 \mathrm{mM} \mathrm{NaF}$ and $10 \mathrm{mM}$ EDTA (pre-incubated at $30^{\circ}$ ), containing either 0.1 or $10 \mathrm{mM}$ glucose- 6 phosphate, the reaction was initiated by supplementing $0.2 \mathrm{mM}\left[\mathrm{U}-{ }^{14} \mathrm{C}\right] \mathrm{UDP}$-glucose $(10 \mu \mathrm{Ci})$, after $15 \mathrm{~min}$ the reaction was terminated by the addition of $2.5 \mathrm{~mL}$ of ice-cold $66 \%$ ethanol and filtration over pre-wetted Whatman GF/C glass fibre discs. The filters were washed, dried and counted for radioactivity. Blanks were assayed by adding the homogenate to tubes containing the complete reaction mixture plus ice-cold ethanol. The fractional velocity as the parameter for the portion of glycogen synthase active in vivo (I-form) toward the total enzyme contents ( $\mathrm{I}-+\mathrm{D}$-forms) at the time-point of homogenization was calculated as the ratio between the activities measured at 0.1 (I-form) and $10 \mathrm{mM}$ glucose-6-phosphate (I- + D-forms) [20].

$G P A T$. This was assayed as described previously [21], with the following modifications. The incubation mixture contained $50 \mathrm{mM}$ Tris- $\mathrm{HCl}(\mathrm{pH} 7.4), 200 \mathrm{mM}$ $\mathrm{KCl}, 1 \mathrm{mM}$ DTT, $150 \mu \mathrm{M}$ palmitoyl-CoA, $2 \mathrm{mg} / \mathrm{mL}$ BSA, $0.2 \mathrm{mM}\left[{ }^{3} \mathrm{H}\right]$ glycerol-3-phosphate $(2 \mu \mathrm{Ci})$ and homogenate from $3 \mathrm{~T} 3$ adipocytes (see above) in a final volume of $0.5 \mathrm{~mL}$. The reaction was started by addition of $50 \mu \mathrm{L}$ of homogenate. After incubation $\left(3 \mathrm{~min}, 37^{\circ}\right.$ ) the reaction was stopped with $2 \mathrm{~mL}$ of water-saturated butanol, followed by $1.5 \mathrm{~mL}$ of butanol-saturated water. The butanol phase was separated and washed twice. An aliquot was counted for radioactivity. Under these conditions the rate of product formation was linear for at least $15 \mathrm{~min}$. The radiolabelled products formed were primarily phosphatidic acid (65-70\%) and lysophosphatidic acid $(20-25 \%)$, as determined by TLC (not shown).

$P K A$. This was assayed according to a published method [22], with the following modifications. The reaction mixture contained $25 \mu \mathrm{L}$ of rat adipocyte cytosol, $0.4 \mu \mathrm{M}$ kemptide, $40 \mathrm{mM}$ Tris- $\mathrm{HCl}$ ( $\mathrm{pH} 7.2$ ), $2 \mathrm{mM}$ DTT, $12.5 \mathrm{mM} \mathrm{MgCl} 2,0.1 \mathrm{mM}$ PMSF, $1 \mathrm{mM}$ IBMX, $100 \mu \mathrm{M}\left[\gamma_{-}{ }^{32} \mathrm{P}\right] \mathrm{ATP}(1 \mu \mathrm{Ci})$ with or without $1 \mu \mathrm{M}$ cAMP in a total volume of $100 \mu \mathrm{L}$. After incubation $\left(10 \mathrm{~min}, 30^{\circ}\right)$ the reaction mixture was chilled on ice, then supplemented with $3 \mathrm{~mL}$ of $75 \mathrm{mM}$ phosphoric acid, $100 \mathrm{mM} \mathrm{NaF}$ and $10 \mathrm{mM}$ ATP, and immediately spotted on phosphocellulose filters (Whatman P18). After extensive washing with $75 \mathrm{mM}$ phosphoric acid, the filters were dried and counted for radioactivity. The PKA activity was expressed as the ratio between ${ }^{32} \mathrm{P}$-incorporation into kemptide with and without cAMP. This activity ratio is a parameter for the portion of PKA active in vivo toward total cellular PKA at the time-point of homogenization [23].

$c A M P$-specific $P D E$. This was assayed as described previously $[24,25]$, with the following modifications. $\mathrm{Up}$ to $50 \mu \mathrm{L}$ of LDM from rat adipocytes were incubated $\left(5 \mathrm{~min}, 30^{\circ}\right)$ with $500 \mathrm{nM}\left[2,8-{ }^{3} \mathrm{H}\right] \mathrm{cAMP}$ $(100 \mathrm{nCi})$ in $50 \mathrm{mM}$ Tris- $\mathrm{HCl}(\mathrm{pH} \mathrm{7.4)}, 0.5 \mathrm{mM}$ DTT, $5 \mathrm{mM} \mathrm{MgCl} 2$ and $50 \mu \mathrm{M}$ PMSF in a total volume of $0.25 \mathrm{~mL}$. The incubation was terminated by the 
sequential addition of $30 \mu \mathrm{L}$ of $10 \mathrm{mM}$ IBMX and $120 \mu \mathrm{L}$ of $0.1 \mathrm{~N} \mathrm{HCl}$ and heating $\left(5 \mathrm{~min}, 95^{\circ}\right)$. After neutralization $[120 \mu \mathrm{L}$ of $0.1 \mathrm{~N} \mathrm{KOH}$ and $80 \mu \mathrm{L}$ of $250 \mathrm{mM}$ Tris- $\mathrm{HCl} / \mathrm{pH} \mathrm{7.4],} 10 \mu \mathrm{L}$ of crude $5^{\prime}-$ nucleotidase $(5 \mathrm{mg} / \mathrm{mL}$ ) (Crotalus atrox) was added to the mixture. The reaction $\left(30 \mathrm{~min}, 37^{\circ}\right)$ was terminated by the addition of $60 \mu \mathrm{L}$ of $200 \mathrm{mM}$ EDTA and $5 \mathrm{mM}$ adenosine. Unreacted cAMP was removed by the addition of $1 \mathrm{~mL}$ of a $1: 3$ slurry of Dowex AG-1X8 (Biorad, München, Germany). Solutions were shaken ( $\left.5 \mathrm{~min}, 4^{\circ}\right)$ and centrifuged $(1000 \mathrm{~g}, 5 \mathrm{~min})$. Radiolabelled adenosine remaining in the supernatant was determined by liquid scintillation counting. The assay was proportional up to $100 \mu \mathrm{g}$ of protein and linear for $20 \mathrm{~min}$.

Determination of $C A M P$ levels. Rat adipocytes were homogenized $\left(4^{\circ}\right)$ in the incubation medium $\left(0.4 \mathrm{~mL} 5 \times 10^{5}\right.$ cells $\left./ \mathrm{mL}\right)$ with $0.6 \mathrm{~mL}$ of ice-cold $10 \%$ TCA. After $2 \mathrm{~min}$ on ice and subsequent centrifugation $\left(12,000 \mathrm{~g}, 5 \mathrm{~min}, 0^{\circ}\right)$, the supernatant was extracted with diethyl ether and used for determination of the cAMP concentration in the organic phase by a radioimmunoassay kit (Amersham-Buchler, Braunschweig, Germany).

Lipolysis. This was assayed as the release of glycerol or fluorescent fatty acids from prelabelled rat adipocytes. For fluorescent labelling of adipocyte lipids, $12 \mathrm{~mL}$ of adipocyte suspension $\left(2.5 \times 10^{5}\right.$ cells/mL of HEPES-based Krebs-Ringer buffer containing $0.5 \mathrm{mM}$ glucose and $0.75 \%$ BSA) was incubated $\left(90 \mathrm{~min}, 37^{\circ}\right)$ with $0.3 \mathrm{nM}$ insulin and $0.1 \mathrm{mM}$ 12-((7-nitrobenz-2-oxa-1,3-diazol-4yl)amino) dodecanoic acid. Subsequently, the adipocytes were washed four times with $50 \mathrm{~mL}$ DMEM containing $5.5 \mathrm{mM}$ glucose, $3 \% \mathrm{BSA}$ and antibiotics by flotation $(250 \mathrm{~g}, 1 \mathrm{~min})$, suspended in the same medium at $5 \%$ lipocrit, incubated $(15 \mathrm{~min}$, $37^{\circ}$ ) with $1 \mu \mathrm{M}$ isoproterenol and then supplemented with sulphonylurea or insulin. After incubation $(4 \mathrm{hr}$, $37^{\circ}$ ), $1 \mathrm{~mL}$ aliquots were filtered (Whatman $\mathrm{GF} / \mathrm{C}$ glass fibre filters). Portions of the filtrate (which quantitatively contained the released glycerol and fatty acids as well as degradation products derived thereof) were used for determination of glycerol and fluorescent fatty acids. For fatty acid determination, $500 \mu \mathrm{L}$ of the filtrate were dried under vacuum, dissolved in $50 \mu \mathrm{L}$ tetrahydrofurane and $5 \mu \mathrm{L}$ aliquots were analysed by TLC [silica gel Si60, acetic acid:petrol ether: ethanol $(3.5: 1.5: 0.5) \mathrm{v} / \mathrm{v}]$. The total amount of fluorescent fatty acid and degradation products was calculated by fluorometric scanning of the TLC plate (total area). For glycerol determination, $200 \mu \mathrm{L}$ of the filtrate were added to $800 \mu \mathrm{L}$ water, heated $\left(10 \mathrm{~min}, 70^{\circ}\right)$ and then successively made $3 \%(\mathrm{v} / \mathrm{v})$ perchloric acid and $13 \%$ $(\mathrm{v} / \mathrm{v})$ carbon tetrachloride. The samples were mixed and centrifuged $(12,000 \mathrm{~g}, 5 \mathrm{~min})$. After neutralization with $\mathrm{KOH}$ the supernatant was assayed for glycerol using the spectrophotometric method of Wieland [26].

Immunoblot analysis of GLUT4. This was performed with polyclonal affinity-purified rabbit antibodies raised against a synthetic peptide corresponding to the $\mathrm{COOH}$-terminal domain of rat GLUT4 (residues 495-509) [27]. The plasma membrane and LDM fractions were subjected to (a)

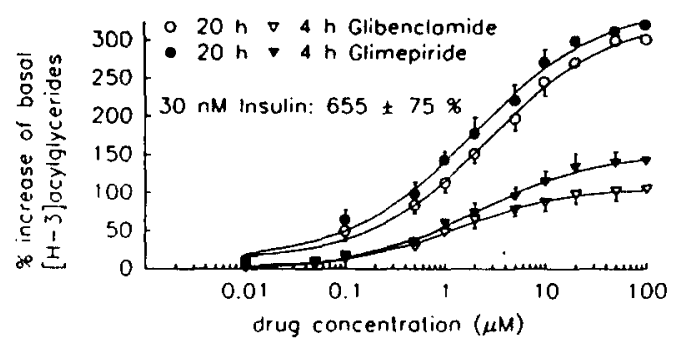

(b)

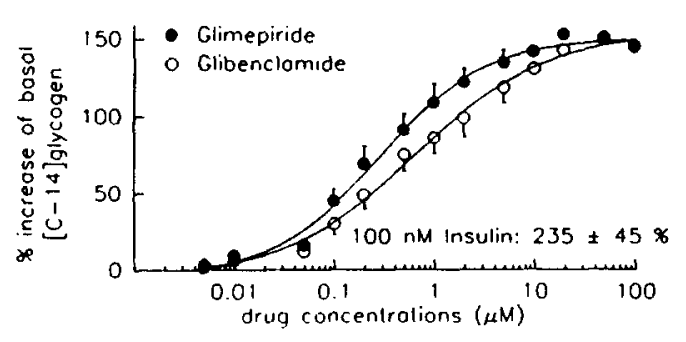

Fig. 1(a). Lipogenesis in 373 adipocytes was tested after incubation of $35 \mathrm{~mm}$ plates with the indicated concentrations of glimepiride and glibenclamide for 4 and $20 \mathrm{hr}$, or insulin for $15 \mathrm{~min}$. The ${ }^{3} \mathrm{H}$-incorporation in to toluene-extractable material measured for the basal state (in the absence of drug or insulin) and corrected for a blank value (incubation mixture lacking cells) was set at $100 \%$. Each point represents the mean ( $\pm S D$; only one-half of the error bars are shown due to space limitations) of four different cell preparations with four determinations (b) Glycogenesis in isolated rat diaphragms was assayed after incubation with the indicated concentrations of glimepiride and glibenclamide for $4 \mathrm{hr}$ or insulin for $30 \mathrm{~min}$. The ${ }^{14} \mathrm{C}$ incorporation into ethanol-precipitated glycogen measured for the basal state (in the absence of drug or insulin) was set at $100 \%$. Each point represents the mean ( \pm SD) of six different diaphragm preparations with four determinations each.

SDS-PAGE (25 $\mu \mathrm{g}$ protein/lane) and electrophoretically transferred onto nitrocellulose filters [28]. Incubations of the filters with primary and secondary antibodies ( ${ }^{125} \mathrm{I}$-anti-rabbit IgG from goat), autoradiography and quantitative evaluation of the immunoreactive material by densitometry were carried out as described previously [12].

Immunoprecipitation of GLUT4. This was performed according to published procedures [29] with the following modifications: $200 \mu \mathrm{L}$ of homogenate $(100 \mu \mathrm{g}$ of protein) were centrifuged $(150,000 \mathrm{~g}$, $60 \mathrm{~min}, 4^{\circ}$ ), the pellet was dissolved in $50 \mu \mathrm{L}$ of $10 \mathrm{mM}$ Tris- $\mathrm{HCl}$ (pH 8.0), $1 \mathrm{mM}$ EDTA, $6 \mathrm{M}$ urea and $5 \%$ SDS, heated $\left(60^{\circ}, 5 \mathrm{~min}\right)$ and again centrifuged. The supernatant was supplemented with $2.5 \mathrm{~mL}$ of immunoprecipitation buffer [29] containing $1 \% \mathrm{TX}-100$ and then with $50 \mu \mathrm{L}$ antiGLUT4 antibody which had been adsorbed to protein A-Sepharose $(50 \mu \mathrm{L}$ of antiserum was incubated with $50 \mathrm{mg}$ protein A-Sepharose beads in 


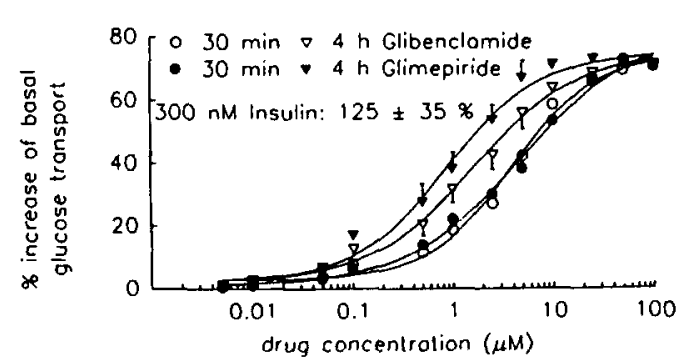

(b)

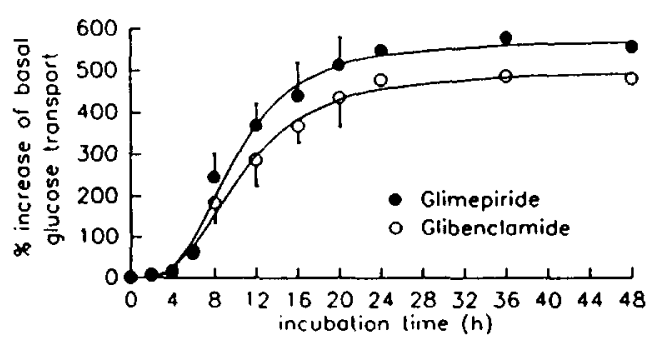

(a)

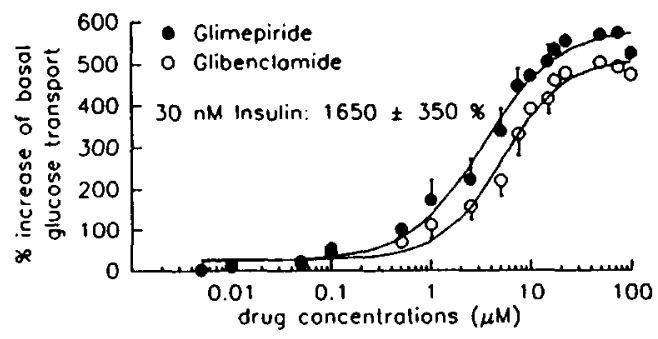

(c)

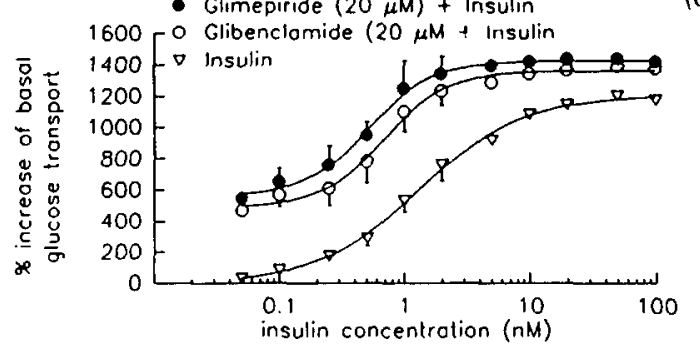

(d)

Fig. 2(a). 2-Deoxyglucose transport into isolated rat diaphragms was assayed after incubation with the indicated concentrations of glimepiride and glibenclamide or $300 \mathrm{nM}$ insulin for $30 \mathrm{~min}$ or $4 \mathrm{hr}$. The diaphragm-associated ${ }^{3} \mathrm{H}$-radioactivity measured for the basal state (in the absence of drug or insulin) and corrected for non-specific trapping (in the presence of $25 \mu \mathrm{M}$ cytochalasin B) was set at $100 \%$. Each point represents the mean ( \pm SD) of four different diaphragm preparations with four determinations each. (b)-(d) 2-Deoxyglucose transport into $3 \mathrm{~T} 3$ adipocytes was assayed after incubation of $35 \mathrm{~mm}$ plates for various periods (panel b) or $20 \mathrm{hr}$ (panels $\mathrm{c}$ and d) with $20 \mu \mathrm{M}$ glimepiride and glibenclamide (panels $b$ and $d$ ) or the indicated drug concentrations or $30 \mathrm{nM}$ insulin (panel c) prior to further incubation in the absence (panels $b$ and $c$ ) or presence of various concentrations of insulin (panel $d$ ) for $15 \mathrm{~min}$. The cell-associated ${ }^{3} \mathrm{H}$-radioactivity measured for the basal state (in the absence of drug or insulin) and corrected for non-specific trapping (in the presence of $25 \mu \mathrm{M}$ cytochalasin B) was set at $100 \%$. Each point represents the mean $( \pm S D$ ) of five different cell preparations with four determinations each.

$450 \mu \mathrm{L}$ immunoprecipitation buffer for $2 \mathrm{hr}$ at $4^{\circ}$ under head-over rotation. The beads were centrifuged, washed twice with buffer and finally suspended in $0.5 \mathrm{~mL}$ of buffer). After incubation ( $10 \mathrm{hr}, 4^{\circ}$, head-over rotation), the immunoprecipitates were collected by centrifugation $(12,000 \mathrm{~g}, 30 \mathrm{sec})$, washed sequentially with $2 \mathrm{~mL}$ of immunoprecipitation buffer containing 0.5 and $0.1 \%$ TX-100 and finally dissolved in $50 \mu \mathrm{L}$ of $10 \mathrm{mM}$ TrisHCl (pH 8.0), 1 mM EDTA, $6 \mathrm{M}$ urea and 2\% SDS. The supernatant of a centrifugation was analysed by SDS-PAGE and fluorography. The relative amount of immunoprecipitated GLUT4 was calculated from spectrophotometric analysis of the silver grains eluted from the darkened areas (bands) of the film [30].

Miscellaneous procedures. Published procedures were used for SDS-PAGE (14\% separating gel) in the presence of $6 \mathrm{M}$ urea, fluorography [31] and protein determination with the amidoblack staining method [32].

\section{RESULTS}

Stimulation of glucose utilization (lipogenesis and glycogenesis)

Long-term incubation of 3T3 adipocytes with glimepiride and glibenclamide concentration-depen- dently stimulated lipogenesis up to 4-fold (corresponding to $35-40 \%$ of the maximal insulininduced lipogenesis as observed with $30 \mathrm{nM}$ insulin after $15 \mathrm{~min}$ incubation) (Fig. 1a). This effect was clearly more pronounced after $20 \mathrm{hr}$ compared to $4 \mathrm{hr}$ incubation. The $\mathrm{ED}_{50}$-values for glimepiride and glibenclamide were comparable (1.7 vs $2.9 \mu \mathrm{M})$ and independent of the incubation time.

Incubation for $4 \mathrm{hr}$ of isolated rat hemidiaphragms with glimepiride and glibenclamide concentrationdependently stimulated glycogenesis up to 2.5 -fold (corresponding to $65 \%$ of the maximal insulin effect as observed with $100 \mathrm{nM}$ insulin after $30 \mathrm{~min}$ incubation) (Fig. 1b), with $\mathrm{ED}_{50}$-values of $0.4 \mu \mathrm{M}$ (glimepiride) and $0.8 \mu \mathrm{M}$ (glibenclamide). Thus, the overall glucose-utilizing pathways of lipid and glycogen synthesis are stimulated by both drugs, with glimepiride being slightly more effective than glibenclamide.

\section{Stimulation of glucose transport}

Under physiological plasma glucose levels glucose transport is thought to be rate-limiting for lipogenesis and glycogenesis [33]. Therefore, it was wondered whether glimepiride and glibenclamide stimulated transport of the non-metabolizable sugar analogue, 2-deoxyglucose, in 3T3 adipocytes and isolated rat diaphragms. Incubation of the diaphragms for $30 \mathrm{~min}$ 
(a)

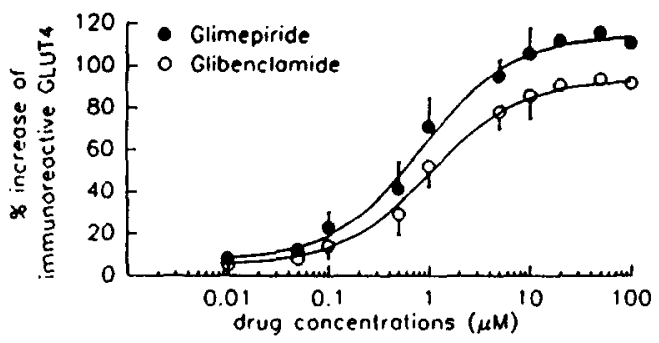

(b)

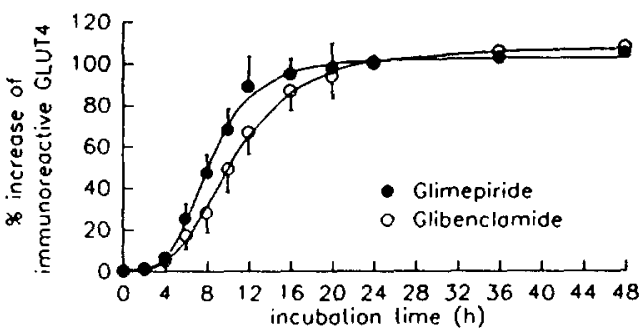

(c)

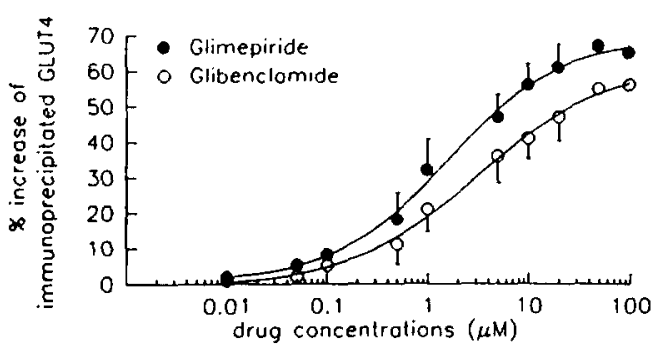

Fig. 3(a) and (b). Total amount of GLUT4 protein in 3T3 adipocytes was assayed after incubation of $150 \mathrm{~mm}$ plates with the indicated concentrations of glimepiride and glibenclamide (panel a) or $20 \mu \mathrm{M}$ drug (panel b) for $20 \mathrm{hr}$ (panel a) or the indicated periods (panel b). The immunoreactive GLUT4 in total cellular membranes measured for the basal state (in the absence of drug or insulin) was set at $100 \%$. Each value represents the mean ( \pm SD) of three different cell preparations with four determinations each. (c) The amount of newly synthesized GLUT4 protein in 3T3 adipocytes (metabolically labelled with ${ }^{35} \mathrm{~S}$ ]methionine) was assayed after incubation of $150 \mathrm{~mm}$ plates with the indicated concentrations of glimepiride and glibenclamide, for $20 \mathrm{hr}$. The immunoprecipitated radiolabelled GLUT4 in total cellular membranes in the basal state (in the absence of drug or insulin) was set at $100 \%$. Each point represents the mean $( \pm \mathrm{SD})$ of three cell preparations with two determinations each.

with glimepiride and glibenclamide concentrationdependently increased glucose transport up to 1.7fold with $\mathrm{ED}_{50}$-values of $3.2 \mu \mathrm{M}$ for both drugs (Fig. 2a). Drug exposure for $4 \mathrm{hr}$ caused a left-ward shift of the dose-response curves $\left(E_{50}\right.$-value $=0.7 \mu \mathrm{M}$ for glimepiride, $1.2 \mu \mathrm{M}$ for glibenclamide) with no increase in the maximal response. In contrast, maximal glimepiride and glibenclamide stimulation of 2-deoxyglucose transport in 3T3 adipocytes required $24 \mathrm{hr}$ drug exposure (Fig. 2b). Under these conditions glimepiride and glibenclamide concentration-dependently stimulated glucose transport up to 7- and 6-fold with $\mathrm{ED}_{50}$-values of 3.2 and $5.2 \mu \mathrm{M}$, respectively (corresponding to $25-30 \%$ of the maximal insulin stimulation) (Fig. 2c). Submaximal insulin concentrations $(0.05-1 \mathrm{nM})$ plus glimepiride or glibenclamide $(20 \mu \mathrm{M})$ stimulated 2deoxyglucose transport in an additive fashion, which. however, did not exceed the maximal insulin effect (Fig, 2d). The $E D_{50}$-value for glucose transport stimulation by insulin $(1.2 \mathrm{nM})$ was reduced in the presence of glimepiride $(0.5 \mathrm{nM})$ and glibenclamide $(0.8 \mathrm{nM})$. Thus, in $3 \mathrm{~T} 3$ adipocytes, both sulphonylureas directly activated glucose transport independently of insulin, and potentiated insulinstimulated glucose transport, albeit to a moderate degree. Stimulation of glucose transport may be based on increased de novo synthesis of GLUT protein and/or recruitment of GLUT from intracellular stores (LDM) to the cell surface (termed as translocation $[34,35])$. To study these possibilities, the amount of GLUT4, the major insulin-regulatable GLUT isoform in $3 T 3$ adipocytes (for a review see Ref. [36]), was determined in total cellular membranes or, after subcellular fractionation, in the LDM and plasma membranes by immunoblotting with anti-GLUT4 antibodies. Incubation $(20 \mathrm{hr})$ of 3T3 adipocytes with glimepiride and glibenclamide concentration-dependently increased the total amount of GLUT4 up to 2-fold (with $20 \mu \mathrm{M}$ drug) (Fig. 3a). Long-term incubation ( $>4 \mathrm{hr}$ ) was required for a significant drug-induced increase, suggesting stimulation of GLUT4 synthesis (Fig. 3b). This was confirmed by immunoprecipitation with anti-GLUT4 antibodies of total membrane proteins from 3T3 adipocytes which had been metabolically labelled with $\left[{ }^{35} \mathrm{~S}\right]$ methionine for $20 \mathrm{hr}$ in the presence of glimepiride or glibenclamide (Fig. 3c). Glimepiride and glibenclamide concentration-dependently increased the amount of total immunoprecipitated radiolabelled GLUT4 1.7- and 1.6-fold (at 50 $\mu \mathrm{M}$ ), respectively, with $\mathrm{ED}_{5(1)}$-values $(1.2$ vs $2.3 \mu \mathrm{M})$ comparable to those observed for total immunoreactive GLUT4 (0.8 vs $1.5 \mu \mathrm{M})$.

In addition, both drugs stimulated translocation of GLUT4 as revealed by immunoblotting of LDM and plasma membranes with anti-GLUT4 antibodies (Table 1). Incubation (20 hr) with glimepiride and glibenclamide caused a concentration-dependent translocation of GLUT4 approaching $40-50 \%$ of the maximal insulin response, corresponding to a $3.5-$ fold increase of plasma membrane GLUT4.

Stimulation of glucose metabolizing enzymes.

In addition to drug-stimulated glucose transport and metabolism, the latter, at least in part, being due to increased substrate availability, glucose metabolizing enzymes may be activated in response to glimepiride and glibenclamide independently of the mass effect. Therefore, the key regulatory enzymes of lipogenesis and glycogenesis, GPAT and glycogen synthase, were investigated.

The esterification of glvcerol-3-phosphate to 
Table 1. Effects of sulphonylureas on the translocation of GLUT4 in 3T3 adipocytes

\begin{tabular}{lcc}
\hline \multicolumn{1}{c}{ Incubation } & \multicolumn{2}{c}{$\begin{array}{c}\text { Total immunoreactive GLUT4 } \\
\text { in the plasma membrane }(\%)\end{array}$} \\
\hline Basal & \multicolumn{2}{c}{$8.3 \pm 2.7$} \\
Insulin & \multicolumn{2}{c}{$44.2 \pm 9.5$} \\
Sulphonylurea $(\mu \mathrm{M})$ & Glimepiride & Glibenclamide \\
0.5 & $8.1 \pm 3.5$ & $6.8 \pm 2.7$ \\
1 & $10.8 \pm 2.6$ & $9.6 \pm 4.0$ \\
5 & $12.9 \pm 3.9$ & $15.9 \pm 4.6$ \\
10 & $16.7 \pm 4.4$ & $20.3 \pm 4.9$ \\
20 & $19.8 \pm 5.3$ & $23.6 \pm 4.1$ \\
50 & $22.2 \pm 4.8$ & $23.1 \pm 5.2$ \\
\hline
\end{tabular}

Translocation of GLUT4 in 3T3 adipocytes was assayed after incubation of $150 \mathrm{~mm}$ plates with the indicated concentrations of glimepiride and glibenclamide for $20 \mathrm{hr}$ or insulin $(5 \mathrm{nM})$ for $30 \mathrm{~min}$.

The amount of immunoreactive GLUT4 identified by immunoblotting in the plasma membranes was calculated as the percentage of the total amount of GLUT4 recovered in cellular membranes after incubation with drug or insulin which was set at $100 \%$ for each concentration. Each value represents the mean ( $\pm \mathrm{SD}$ ) of four adipocyte preparations and fractionations with three determinations each.

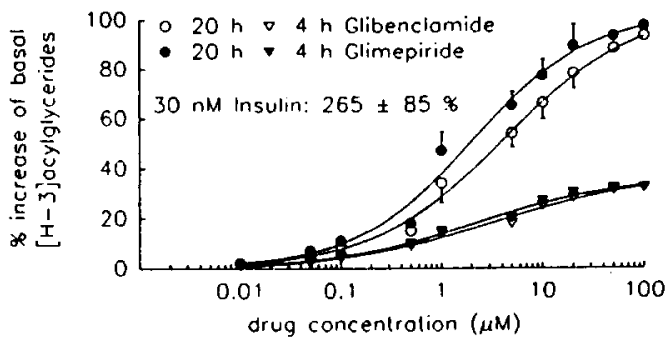

Fig. 4. GPAT activity in the homogenate from isolated rat adipocytes was assayed after incubation of $20 \mathrm{~mL}$ of adipocyte suspension $\left(5 \times 10^{5}\right.$ cells $\left./ \mathrm{mL}\right)$ with the indicated concentrations of glimepiride and glibenclamide for 4 and $20 \mathrm{hr}$, or with $30 \mathrm{nM}$ insulin for $30 \mathrm{~min}$. The ${ }^{3} \mathbf{H}-$ incorporation into butanol-extractable material measured for the basal state (in the absence of drug or insulin) and corrected for a blank value (incubation mixture lacking homogenate protein) was set at $100 \%$. Each point represents the mean ( \pm SD) of five different cell and homogenate preparations with four determinations each.

neutral lipids, phospholipids and (lyso)phosphatidic acid by GPAT was stimulated up to 2-fold with $\mathrm{ED}_{50^{-}}$ values of 1.9 and $3.7 \mu \mathrm{M}$, respectively, when assayed with homogenate from glimepiride- and glibenclamide-treated 3T3 adipocytes (Fig. 4). The concentration-dependent stimulation was more pronounced after $20 \mathrm{hr}$ than $4 \mathrm{hr}$ incubation.

After $4 \mathrm{hr}$ exposure of isolated rat diaphragms to glimepiride and glibenclamide the fractional velocity for glycogen synthase concentration-dependently increased up to 6-fold (at $20 \mu \mathrm{M}$ ) (Fig. 5a). Glimepiride was more effective than glibenclamide

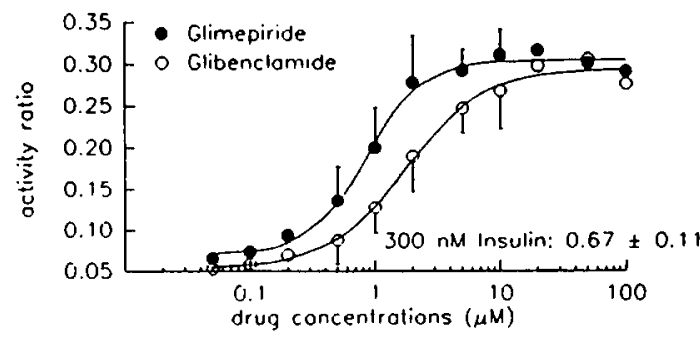

Fig. 5. Glycogen synthase activity ratio in the homogenate of isolated rat diaphragm was assayed after $4 \mathrm{hr}$ incubation with the indicated concentrations of glimepiride and glibenclamide or $300 \mathrm{nM}$ insulin. Each point represents the mean $( \pm S D$ ) of the fractional velocity (see Materials and Methods) of three different diaphragm preparations with four determinations each.

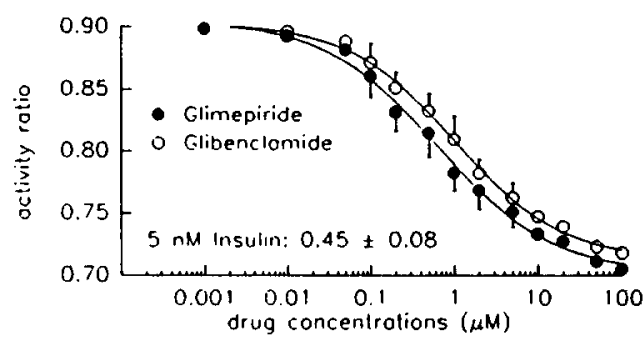

Fig. 6. PKA activity ratio in the cytosol of isolated rat adipocytes was assayed after incubation of $40 \mathrm{~mL}$ of adipocyte suspension $\left(5 \times 10^{5}\right.$ cell $\left./ \mathrm{mL}\right)$ with $1 \mu \mathrm{M}$ isoproterenol for $15 \mathrm{~min}$ and then with the indicated concentrations of glimepiride and glibenclamide or $5 \mathrm{nM}$ insulin for $4 \mathrm{hr}$. Each point represents the mean ( \pm SD) of the activity ratio (see Materials and Methods) of three different adipocyte preparations with three determinations each.

( $\mathrm{ED}_{50} 0^{- \text {-value }} 0.8$ vs $2.0 \mu \mathrm{M}$ ). Gel filtration over Sephadex G-25 of homogenates prepared from drugtreated diaphragms did not inhibit the activation of glycogen synthase (data not shown), suggesting that the activation was not due to elevated levels of glucose-6-phosphate as a consequence of increased glucose transport. Total glycogen synthase activity (I- and D-forms) as measured in the presence of $10 \mathrm{mM}$ glucose-6-phosphate was not altered. Both drugs (at $10 \mu \mathrm{M}$ ) and low concentrations of insulin (up to $10 \mathrm{nM}$ ) stimulated the fractional velocity in an additive fashion (data not shown), approaching $120 \%$ of the maximal insulin effect. The $\mathrm{ED}_{50}$-value for insulin stimulation ( $35 \mathrm{nM})$ was reduced in the presence of glimepiride $(16 \mathrm{nM})$ or glibenclamide $(23 \mathrm{nM})$. Elevated basal and insulin-stimulated fractional velocities were not observed if the homogenate was prepared $15 \mathrm{~min}$ after drug addition.

\section{Effects on the CAMP regulatory cascade}

GPAT and glycogen synthase, which are both stimulated by glimepiride and glibenclamide in 3T3 adipocytes and the rat diaphragm, are regulated 
Table 2. Effects of sulphonylureas on the isoproterenolstimulated lipolysis in rat adipocytes

\begin{tabular}{lcc}
\hline \multicolumn{1}{c}{ Incubation } & \multicolumn{2}{c}{ Total glycerol release } \\
$(\%)$ \\
\hline Insulin & \multicolumn{2}{c}{$30.6 \pm 8.9$} \\
Sulphonylurea $(\mu \mathrm{M})$ & Glimepiride & Glibenclamide \\
0.5 & $92.8 \pm 15.8$ & $95.2 \pm 12.4$ \\
1 & $76.4 \pm 18.9$ & $82.0 \pm 19.3$ \\
2 & $70.8 \pm 14.5$ & $68.4 \pm 12.5$ \\
5 & $63.6 \pm 11.6$ & $58.7 \pm 10.4$ \\
10 & $60.1 \pm 14.2$ & $48.8 \pm 16.7$ \\
20 & $56.5 \pm 8.9$ & $44.8 \pm 12.0$ \\
50 & $53.1 \pm 12.7$ & $42.7 \pm 9.7$ \\
& Fluorescent fatty acid release \\
& \multicolumn{3}{c}{$(\%)$} \\
\hline Insulin & \multicolumn{2}{c}{$36.7 \pm 10.3$} \\
Sulphonylurea $(\mu \mathrm{M})$ & Glimepiride & Glibenclamide \\
0.5 & $91.7 \pm 24.9$ & $95.7 \pm 17.8$ \\
1 & $76.3 \pm 19.4$ & $86.4 \pm 28.1$ \\
2 & $72.3 \pm 14.1$ & $73.7 \pm 18.5$ \\
5 & $67.3 \pm 20.5$ & $69.6 \pm 16.4$ \\
10 & $63.1 \pm 13.1$ & $64.7 \pm 18.6$ \\
20 & $58.3 \pm 19.4$ & $59.7 \pm 12.1$ \\
50 & $56.3 \pm 10.5$ & $55.3 \pm 13.6$ \\
\hline
\end{tabular}

Isoproterenol-stimulated lipolysis was assayed as glycerol and fatty acid release from rat adipocytes (pre-labelled with fluorescent fatty acids) after incubation of $50 \mathrm{~mL}$ of adipocyte suspension $\left(5 \times 10^{5}\right.$ cells $\left./ \mathrm{mL}\right)$ in the presence of $1 \mu \mathrm{M}$ isoproterenol for $15 \mathrm{~min}$ and subsequently with the indicated concentrations of glimepiride and glibenclamide or $5 \mathrm{nM}$ insulin for $4 \mathrm{hr}$.

The amount of glycerol and fluorescent fatty acid (and degradation products) recovered in the cell-free filtrate from isoproterenol-treated adipocytes which had not been incubated with drug or insulin was set at $100 \%$. Each value represents the mean $( \pm S D)$ of three different adipocyte preparations with four determinations each.

by cAMP-dependent phosphorylation leading to inactivation. Therefore, the effect of the two sulphonylureas on the cAMP metabolism and on the activity of PKA in isolated rat adipocytes, which had been challenged for $\beta$-adrenergic response by preincubation with isoproterenol, were studied. The PKA activity ratio was high after isoproterenol stimulation of rat adipocytes and was reduced by subsequent sulphonylurea treatment (4 hr, Fig. 6). The concentration-dependent inhibition of PKA approached up to $40 \%$ of the maximal insulin effect and was slightly more pronounced for glimepiride than glibenclamide $\left(\mathrm{IC}_{50}=0.66\right.$ vs $\left.1.3 \mu \mathrm{M}\right)$.

To corroborate the inhibitory effect of glimepiride and glibenclamide on PKA activity, it was then studied whether the low PKA activity ratio was correlated with diminished lipolysis. Glimepiride and glibenclamide antagonized the isoproterenolstimulated lipolysis in isolated rat adipocytes (Table 2). The parallel concentration-dependent inhibition of glycerol and fatty acid release was first observed $30 \mathrm{~min}$ after drug addition (data not shown) and reached a maximum after $4 \mathrm{hr}$ with $50 \mu \mathrm{M}$ drug (corresponding to the half-maximal insulin effect).
The PKA activity ratio is assumed to reflect mainly the intracellular cAMP concentration at the timepoint of homogenization [23]. Consequently, it was studied whether glimepiride and glibenclamide caused a reduction in the high cytosolic cAMP level in isoproterenol-stimulated adipocytes. Care was taken to minimize degradation of cytosolic cAMP after homogenization of the isoproterenol- and, subsequently, drug-treated cells (see Materials and Methods). Both drugs provoked a concentrationdependent decline of cAMP levels up to $50 \%$ of the isoproterenol-induced concentration (Table 3). Finally, it was studied whether sulphonylureas reduced cytosolic cAMP by promoting its degradation. In fact, the activity of the particulate low $K_{m}$ cAMP-specific PDE in LDM from rat adipocytes which had been incubated with glimepiride and glibenclamide for $2 \mathrm{hr}$ concentration-dependently increased up to 2 -fold (at $20 \mu \mathrm{M}$ ) compared to untreated control cells (Fig. 7), with $\mathrm{ED}_{50}$-values of 0.9 and $2.0 \mu \mathrm{M}$, respectively.

\section{DISCUSSION}

A large number of studies during the past three decades have demonstrated multiple effects of sulphonylurea drugs on isolated normal and insulinresistant rat $[12,37-43]$ and mouse 3 T3 adipocytes [44-46], cultured myocytes [47-51], isolated rat diaphragms [52] and perfused rat hind limbs [53] (for a review see Ref. [54]). Among them are the stimulation of glucose transport $[12,37,38,41,44$ 53], lipogenesis [40] and glycogenesis [43], as well as the inhibition of lipolysis [39]. The multiple effects of sulphonylureas on glucose utilization in vitro suggest the induction of one or several basic molecular mechanism(s) which is(are) responsible for the regulation of key metabolic pathways.

As described in this study, the maximal 7-fold stimulated glucose transport in 3T3 adipocytes after $20 \mathrm{hr}$ incubation with glimepiride and glibenclamide is explained in part by the 4-fold amount of plasma membrane GLUT4. This may be based on both activated synthesis and translocation of GLUT4. Stimulation of GLUT gene expression and translocation by tolbutamide and glibenclamide has been described previously for adipose $[41,42,44]$ and muscle cells $[48,50]$. Since glimepiride and insulin stimulations are additive only, glimepiride may regulate GLUT4 translocation by bypassing the insulin signal transduction cascade. Elevated levels of phosphorylated GLUT4 in isolated rat adipocytes incubated with glucose, insulin and glutamine in primary culture [12], or in rat adipocytes isolated from Streptozotocin-diabetic rats [55], have been correlated with diminished glucose transport activity [56]. There is some evidence for Ser/Thr-phosphorylation of GLUT4 by PKA during induction of insulin resistance [57-59]. Treatment of insulinresistant cultured adipocytes with glimepiride reduces the GLUT4 phosphorylation state to a significantly higher degree than insulin [12], possibly by interference with PKA activity. This would explain the drug's ability to induce GLUT4 translocation in insulin-resistant adipocytes if only the dephos- 
Table 3. Effects of sulphonylureas on the cAMP-level in rat adipocytes

\begin{tabular}{lcc}
\hline \multicolumn{1}{c}{ Incubation } & \multicolumn{2}{c}{ cAMP [pmol/10 $0^{6}$ adipocytes] } \\
\hline Basal & \multicolumn{2}{c}{$26.3 \pm 6.5$} \\
Isoproterenol & \multicolumn{2}{c}{$175.6 \pm 23.7$} \\
Isoproterenol + insulin & $52.5 \pm 13.6$ \\
Isoproterenol + sulphonylurea $(\mu \mathrm{M})$ & Glimepiride & Glibenclamide \\
0.5 & $168.7 \pm 44.3$ & $173.4 \pm 34.6$ \\
1 & $161.0 \pm 29.6$ & $164.5 \pm 38.9$ \\
2 & $148.8 \pm 21.3$ & $154.1 \pm 40.6$ \\
5 & $127.8 \pm 23.4$ & $138.2 \pm 25.6$ \\
10 & $113.8 \pm 27.6$ & $120.8 \pm 18.9$ \\
20 & $103.3 \pm 31.6$ & $112.2 \pm 26.7$ \\
50 & $110.4 \pm 20.5$ & $124.5 \pm 29.8$ \\
100 & $122.5 \pm 23.1$ & $129.5 \pm 22.4$ \\
\hline
\end{tabular}

cAMP levels in the cytosol of isolated rat adipocytes were assayed after incubation of $20 \mathrm{~mL}$ of adipocyte suspension $\left(5 \times 10^{5}\right.$ cells $\left./ \mathrm{mL}\right)$ in the absence (basal) or presence of $1 \mu \mathrm{M}$ isoproterenol for $15 \mathrm{~min}$ and subsequently with the indicated concentrations of glimepiride and glibenclamide or $5 \mathrm{nM}$ insulin for $4 \mathrm{hr}$. Each value represents the mean ( \pm SD) of four different adipocyte preparations with four determinations each.

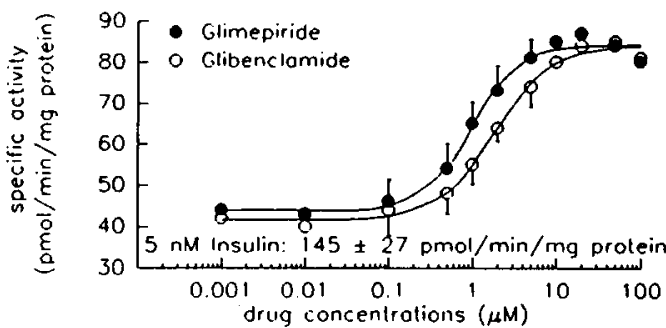

Fig. 7. cAMP-specific PDE activity in LDM from isolated rat adipocytes was assayed after $2 \mathrm{hr}$ incubation of $40 \mathrm{~mL}$ of adipocyte suspension $\left(5 \times 10^{5}\right.$ cells $\left./ \mathrm{mL}\right)$ with the indicated drug concentrations or $5 \mathrm{nM}$ insulin. Each point represents the mean ( \pm SD) of five different adipocyte preparations with two determinations each.

phorylated GLUT4 is competent for translocation and residence at the plasma membrane.

Glimepiride and glibenclamide lead to activation of GPAT and glycogen synthase presumably through impairment of cAMP-dependent phosphorylation of the enzymes. This is also the mechanism for their stimulation by insulin $[60,61]$, and would parallel the postulated molecular mechanism for the glimepiride stimulation of GLUT4 translocation. In support of this hypothesis is the fact that glimepiride and glibenclamide reduce the portion of active PKA within the same concentration range effective in stimulating glucose transport. A moderate inhibition of PKA has been described previously for tolbutamide [62]. The diminished PKA activity is due mainly to significantly lowered levels of cytosolic cAMP after glimepiride- and glibenclamide-treatment of rat adipocytes. However, a direct inhibition of the catalytic subunit of PKA, cannot be excluded, as it has been demonstrated for PKA from rat liver $[63,64]$. In parallel with reduced cytosolic cAMP levels, the drugs stimulate the activity of the microsomal low $K_{m}$ cAMP-specific PDE in rat adipocytes within the same concentration range. This corroborates previous reports concerning sulphonylurea action on PDE activity $[65,66]$. At present it is not known whether a sulphonylureainduced inhibition of adenylate cyclase, as reported for rat heart and liver [67], supports the decline of cAMP levels. The inhibitory effects of glimepiride and glibenclamide on cAMP level and PKA activity are confirmed by the antagonism of isoproterenolstimulated lipolysis in drug-treated rat adipocytes. Significantly less pronounced antilipolytic activity has been demonstrated for tolbutamide [39].

That treatment of 3T3 adipocytes with glimepiride stimulates a glycosyl-phosphatidylinositol-specific phospholipase $C$ [10] may be of relevance for a unifying molecular basis for the inhibition of PKA and stimulation of PDE by sulfonylureas. The degradation products of glycosyl-phosphatidylinositol lipids and/or glycosyl-phosphatidylinositolanchored membrane proteins, phosphoinositolglycans and phosphoinositolglycan-peptides, have been documented to inhibit PKA $[68,69]$ and to stimulate PDE [70, 71] if assayed in cell-free systems derived from adipocytes or hepatocytes which have been pre-incubated with these structures.

The physiological meaning of the stimulation of glucose utilization and inhibition of lipolysis by sulphonylureas observed in vitro is still a matter of intense debate (for two opposing views see Refs. $[54,72])$. The $E_{50}$-values of glimepiride and glibenclamide in these in vitro assays were two to three orders of magnitude higher than the concentration of free not protein-bound drug, as usually measured in the serum of NIDDM patients $(1-10 \mathrm{nM})$. However, local accumulation of sulphonylureas in muscle and fat tissues cannot be excluded. Extra-pancreatic effects have been thought to be responsible for the hypoglycemic action of sulphonylureas following the acute phase of insulin 
release [73-75; for a review see Ref. 76]. In rabbits and dogs the blood sugar lowering phase after the initial period of insulin release is significantly longer for glimepiride than for glibenclamide [9]. To support extra-pancreatic effects this difference should be reflected in the effects of the two drugs on glucose utilization and its underlying regulatory mechanisms in vitro. The present study reveals that, at this level, glimepiride and glibenclamide exhibit similar effective concentration ranges and maximal responses. However, the data obtained from many assays of glimepiride and glibenclamide resulted in slightly lower calculated $\mathrm{ED}_{50^{-}}$and $\mathrm{IC}_{50^{-}}$-values, respectively. This is reflected in subtle left-ward shifts of the dose-response curves for glimepiride. The differences obtained with these experimental designs were only at the threshold of significance. Nevertheless, they were obtained with a considerable number of independent assays carried out with different cell types. Taken together, the present study strengthens the view that: (1) the multiple effects of sulphonylureas on fat and muscle cells in vitro are based on a common molecular mechanism, i.e. the inhibition of cAMP-dependent phosphorylation, which is used by glimepiride slightly more efficiently than by glibenclamide; (2) the prolonged hypoglycemic action of sulphonylureas in the absence of correspondingly elevated plasma insulin levels in vivo, which is more pronounced with glimepiride than glibenclamide, is correlated with their efficacy in stimulating glucose utilization and the underlying regulatory steps in muscle and fat tissues.

Acknowledgements-We thank S. Grey for technical assistance during some experiments, Drs A. Diedenhofen and $E$. Draeger for valuable discussions throughout the course of the study, Dr P. Schindler for suggesting the use of fluorescent fatty acids for the lipolysis assay and $\mathbf{M}$. Forster (all Hoechst AG Frankfurt) for critical reading of the manuscript.

\section{REFERENCES}

1. Yalow RS, Black $\mathrm{H}$, Villazon $\mathbf{M}$ and Berson SA, Comparison of plasma insulin levels following administration of tolbutamide and glucose. Diabetes $\mathbf{9}$ : $356-362,1960$

2. Kolterman OG, Gray RS, Shapiro G, Scarlett JA, Griffin J and Olefsky JM. The acute and chronic effect of sulfonylurea therapy in type II diabetic patients. Diabetes 33: 346-354, 1984.

3. Hirshman MF and Horton ES, Glyburide increases insulin sensitivity and responsiveness in peripheral tissues of the rat as determined by the glucose clamp technique. Endocrinology 126: 2407-2411, 1990.

4. Putnam WS, Anderson DK, Jones RS and Lebovitz HE, Selective potentiation of insulin-mediated glucose disposal in normal dogs by the sulfonylurea glipizide. $J$ Clin Invest 67: 1016-1023, 1981.

5. Lebovitz HE, Feiglos MN, Bocholtz HK and Lebovitz FL, Potentiation of insulin action: a probable mechanism for the anti-diabetic action of sulfonylurea drugs. J Clin Endocrinol Metab 45: 601-604, 1977.

6. Mandarino LJ and Gerich JE, Prolonged sulfonylurea administration decreases insulin resistance and increases insulin secretion in non-insulin dependent diabetes mellitus: evidence for improved insulin action at a postreceptor site in hepatic as well as extrahepatic tissues. Diabetes Care 7 (Suppl 1): 89-99, 1984.

7. Caren $\mathrm{R}$ and Corbo L, The potentiation of exogenous insulin by tolbutamide in depancreatized dogs. $J$ Clin Invest 36: 1546-1550, 1957.

8. Simonson DC, Ferrannini E, Bevilacqua S, Smith D, Barrett E, Carlson R and DeFronzo RA, Mechanism of improvement in glucose metabolism after chronic glyburide therapy. Diabetes 33: 838-845, 1984.

9. Geisen K. Special pharmacology of the new sulfonylurea glimepiride. Drug Res 38: 1120-1130, 1988.

10. Müller G, Dearey EA and Pünter J, The sulphonylurea drug, glimepiride, stimulates release of glycosylphosphatidylinositol-anchored plasma membrane proteins from 3T3 adipocytes. Biochem J 289: 509-521, 1993.

11. Müller G, Hartz D. Pünter J, Ökonomopulos R and Kramer W, Differential interaction of glimepiride and glibenclamide with the $\beta$-cell sulfonylurea receptor $\mathbf{I}$. Binding characteristics. Biochim Biophys Acta 1191 267-277, 1994.

12. Müller $G$ and Wied $S$, The sulfonylurea drug, glimepiride, stimulates glucose transport, glucose transporter translocation and dephosphorylation in insulin resistant rat adipocytes in vitro. Diabetes 42: 1852-1867, 1993

13. Avruch $\mathbf{J}$ and Hoelzl-Wallach DF, Preparation and properties of plasma membranes and endoplasmic reticulum fragments from isolated rat fat cells. Biochim Biophys Acta 233: 334-347, 1971

14. Karnieli E, Zarnowski MJ, Hissin PJ, Simpson JA Salans LB and Cushman SW. Preparation and characterization of plasma membrane fraction from isolated rat fat cells. J Biol Chem 256: 4772-4777, 1981

15. Smith RL and Lawrence JC, Insulin action in denervated rat hemidiaphragms. J Biol Chem 259: 2201-2207, 1984.

16. Moody AJ, Stan MA and Stan M, A simple free fat cell bioassay for insulin. Horm Metab Res 6: 12-16, 1974

17. Lane MD and Frost SC. Evidence for the involvement of vivinal sulfhydryl groups in insulin-activated hexose transport by 3T3-Li adipocytes. I Biol Chem 260: 2646-2652, 1985

18. Clancy BM and Czech MP, Hexose transport stimulation and membrane redistribution of glucose transporter isoforms in response to cholera toxin, dibutyryl cyclic AMP, and insulin in 3T3-L1 adipocytes. $J$ Biol Chem 265: $12,434-12,443,1990$

19. Oron $Y$ and Larner J, A modified rapid filtration assay of glycogen synthase. Anal Biochem 94: 409-410, 1979.

20. Guinovart JJ, Salavert A, Massague J, Ciudad CJ. Salsas E and Itarte E, Glycogen synthase: a new activity ratio assay expressing a high sensitivity to the phosphorylation state. FEBS Lett 106: 284-288, 1979.

21. Lawson N, Jennings RJ. Pollard AD. Sturton RG, Ralph SJ, Marsden, CA, Fears R and Brindley DN. Effects of chronic modification of dietary fat and carbohydrate in rats. Biochem J 200: 265-273, 1981

22. Roskoski R. Assays of protein kinase. Methods Enzymol 99: 3-6. 1983.

23. Honnor RC, Dhillon GS and Londos C, cAMPdependent protein kinase and lipolysis in rat adipocytes. J Biol Chem 260: 15,122-15,129, 1985

24. Kono T, Robinson FW and Sarver JA, Insulin-sensitive phosphodiesterase. J Biol Chem 250: 7826-7835, 1975.

25. Saltiel AR and Steigerwalt RW, Purification of putative insulin-sensitive cAMP phosphodiesterase or its catalytic domain from rat adipocytes. Diabetes 35: 698 704, 1986 .

26. Wieland O, Glycerin UV-Methode. In: Methoden der Enzymatischen Analyse (Ed. Bergmeyer H-U), pp. 1448-1453. Verlag Chemie Weinheim/Bergstraße, 1974 
27. James DE, Strube $\mathbf{M}$ and Mueckler $\mathbf{M}$, Molecular cloning and characterization of an insulin-regulatable glucose transporter. Nature 338: 83-87, 1989.

28. Towbin H, Staehelin T and Gordon J, Electrophoretic transfer of proteins from polyacrylamide gels to nitrocellulose sheets: procedure and some applications Proc Natl Acad Sci USA 76: 4350-4354, 1979.

29. Müller $G$ and Bandlow W, Two lipid-anchored cAMPbinding proteins in the yeast Saccharomyces cerevisiae are unrelated to the $\mathbf{R}$ subunit of cytoplasmic protein kinase A. Eur J Biochem 202: 299-308, 1991.

30. Suissa M, Spectrophotometric quantitation of silver grains eluted from autoradiograms. Anal Biochem 133: 511-514, 1983.

31. Müller $\mathrm{G}$ and Zimmermann R, Import of honeybee prepromelittin into the endoplasmic reticulum: structural basis for independence of SRP and docking protein. EMBO J 7: 2099-2107, 1987.

32. Popov N, Schmitt M, Schulzeck S and Matthies $H$, Eine störungsfreie Mikromethode zur Bestimmung des Proteingehaltes in Gewebehomogenaten. Acta Biol Med Germ 34: 1441-1446, 1975.

33. Klip A and Marette A, Acute and chronic signals controlling glucose transport in skeletal muscle. $J$ Cell Biochem 48: 51-60, 1992.

34. Cushman SW and Wardzala LJ, Potential mechanism of insulin action on glucose transport in the isolated rat adipose cell. J Biol Chem 255: 4758-4762, 1980.

35. Suzuki K and Kono T, Evidence that insulin causes translocation of glucose transport activity to the membrane from an intracellular storage site. Proc Natl Acad Sci USA 77: 2542-2545, 1980.

36. Gould GW and Bell GI, Facilitative glucose transporters: an expanding family. Trends Biochem $S_{c i} 15$ : 18-23, 1990.

37. Farese RV, Ishizuka T, Standaert ML and Cooper DR, Sulfonylureas activate glucose transport and protein kinase $C$ in rat adipocytes. Metabolism 40: 196-200, 1991.

38. Jacobs DB, Hayes, GR and Lockwood DH, Effect of chlorpropamide on glucose transport in rat adipocytes in the absence of changes in insulin binding and receptor-associated tyrosine kinase activity. Metabolism 36: 548-554, 1987.

39. Brown JD, Stone DB and Steele AA, Mechanism of action of antilipolytic agents: comparison of the effects of insulin, tolbutamide, and phenformin on lipolysis induced by dibutyryl cyclic AMP plus theophylline. Metabolism 18: 926-931, 1969.

40. Maloff BL and Lockwood DH, In vitro effects of a sulfonylurea on insulin action in adipocytes. $J$ Clin Invest 68: 85-99, 1981.

41. Jacobs DB and Jung CY, Sulfonylurea potentiates insulin-induced recruitment of glucose transport carrier in rat adipocytes. $J$ Biol Chem 260: 2593-2596, 1985.

42. Jacobs DB, Hayes GR and Lockwood DH, In vitro effects of sulfonylurea on glucose transport and translocation of glucose transporters in adipocytes from streptozocin-induced diabetic rats. Diabetes 38: 205$211,1989$.

43. Altan N, Altan VM, Mikolay L, Larner J and Schwartz $\mathrm{CFW}$, Insulin-like and insulin-enhancing effects of the sulfonylurea glyburide on rat adipose glycogen synthase. Diabetes 34: 281-286, 1985.

44. Tordjman KM, Leingang KA, James DE and Mueckler $M M$, Differential regulation of two distinct glucose transporter species expressed in 3T3-L1 adipocytes: effects of chronic insulin and tolbutamide treatment. Proc Natl Acad Sci USA 86: 7761-7765, 1989.

45. Van Putten JPM and Krans HMJ, Characterization of the sulfonylurea-induced potentiation of the insulin response in cultured $3 \mathrm{~T} 3$ adipocytes. Biochem Pharmacol 35: 2141-2144, 1986.
46. Zuber MX, Wang S-M, Thammavaram KV, Reed DK and Reed BC, Elevation of the number of cell surface insulin receptors and the rate of 2-deoxyglucose uptake by exposure of 3T3-L1 adipocytes to tolbutamide. $J$ Biol Chem 260: 14,045-14,052, 1985.

47. Davidson MB, Molnar G, Furman A and Yamaguch $D$, Glyburide-stimulated glucose transport in cultured muscle cells via protein kinase C-mediated pathway requiring new protein synthesis. Diabetes 40: 1531$1538,1991$.

48. Wang PH, Moller D, Flier JS, Nayak RC and Smith $\mathrm{RJ}$, Coordinate regulation of glucose transporter function, number, and gene expression by insulin and sulfonylureas in L6 rat skeletal muscle cells. $J$ Clin Invest 84: 62-67, 1989.

49. Rogers BJ, Standaert ML and Pollet RJ, Direct effects of sulfonylurea agents on glucose transport in the BC3H-1 myocyte. Diabetes 36: 1292-1296, 1987.

50. Wang PH, Moller D, Flier JS and Smith RJ, Coordinate regulation of glucose transporter function, number, and gene expression in skeletal muscle cells by insulin and sulfonylureas (Abstract). Diabetes 36 (Suppl. 1): 84A, 1987.

51. Cooper RD, Vila, MC, Watson JE, Nair G, Pollet RJ Standaert M and Farese RV, Sulfonylurea-stimulated glucose transport association with diacylglycerollike activation of protein kinase $\mathrm{C}$ in $\mathrm{BC} 3 \mathrm{H} 1$ myocytes. Diabetes 39: 1399-1407, 1990.

52. Standing VF and Foy JM, The effect of glibenclamide on glucose uptake in the isolated rat diaphragm. Postgrad Med J (Suppl): 16-20, 1970.

53. Daniels RL and Lewis SB, Acute tolbutamide administration alone or combined with insulin enhances glucose uptake in the perfused rat hindlimb. Endocrinology 11: 1840-1842, 1982.

54. Gavin III JR, Dual actions of sulfonylureas and glyburide. Am J Med 79 (Suppl 3B): 34-42, 1985.

55. Begum N and Draznin B, Effect of Streptozotocininduced diabetes on GLUT-4 phosphorylation in rat adipocytes. J Clin Invest 90: 1254-1262, 1992.

56. Reusch JE-B, Sussman KE and Draznin B, Inverse relationship between Glut-4 phosphorylation and its intrinsic activity. $J$ Biol Chem 268: 3348-3351, 1993.

57. Kirsch D, Baumgarten M, Denfel T, Rinninger F, Kemmler W and Häring $\mathrm{H}-\mathrm{U}$, Catecholamine-induced insulin resistance of glucose transport in isolated rat adipocytes. Biochem $J$ 216: 737-745, 1986.

58. James DE, Hiken JF and Lawrence Jr JC, Isoproterenol stimulates phosphorylation of the insulin-regulatable glucose transporter in rat adipocytes. Proc Natl Acad Sci USA 86: 8368-8372, 1989.

59. Lawrence Jr JC, Hiken JF and James DE, Stimulation of glucose transport and glucose transporter phosphorylation by okadaic acid in rat adipocytes. $J$ Biol Chem 265: 19,768-19.776, 1990.

60. Vila MdC, Milligan G, Standaert ML and Farese RV, Insulin activates glycerol-3-phosphate acyltransferase (de novo phosphatidic acid synthesis) through a phospholipid-derived mediator. Apparent involvement of $\mathrm{Gi}$ and activation of a phospholipase C. Biochemistry 29: $8735-8740,1990$.

61. Larner J, Insulin and the stimulation of glycogen synthesis. The road from glycogen structure to glycogen synthase to cyclic AMP-dependent protein kinase to insulin mediators. Enzymol Relat Areas Mol Biol 63: 173-231, 1988.

62. Wray $\mathrm{HL}$ and Harris $\mathrm{AW}$, Adenosine 3,5-mono phosphate-dependent protein kinase in adipose tissue: inhibition by tolbutamide. Biochem Biophys Res Commun 53: 291-294, 1973.

63. Okuno S, Inaba M, Nishizawa $Y$, Inoue $A$ and Morii $\mathrm{H}$, Effect of tolbutamide and glyburide on cAMP. 
dependent protein kinase activity in rat liver cytosol. Diabetes 37: 857-861, 1988.

64. Aoki M, Kaku K, Inoue $H$, Matsutani $A$ and Kaneko T, Tolbutamide inhibits cAMP-dependent phosphorylation of liver 6-phosphofructo-2-kinase/ Fructose-2,6-Bisphosphatase. Diabetes 41: 334-338, 1992.

65. Osegawa M, Makino H, Kanatsuka $A$ and Kumagal A, Effects of sulfonylureas on membrane-bound low $K_{m}$ cyclic AMP phosphodiesterase in rat fat cells. Biochim Biophys Acta 721: 289-296, 1982

66. Solomon SS, Deaton J, Shankar TP and Palazzolo M Cyclic AMP phosphodiesterase in diabetes: effect of glyburide. Diabetes 35: 1233-1236, 1986.

67. Leichter SB and Galasky SP, Effects of chlorpropamide and tolbutamide on adenylate cyclase activity in rat heart and liver. Biochem Pharmacol 30: 2861-2863, 1981.

68. Villalba M, Kelly $\mathrm{KL}$ and Mato JM. Inhibition of cAMP-dependent protein kinase by the polar head group of an insulin-sensitive glycophospholipid. Biochim Biophys Acta 968: 69-76, 1988.

69. Misek DE and Saltiel AR, An inositol phosphate glycan derived from a Trypanosoma brucei glycosylphosphatidylinositol mimics some of the metabolic actions of insulin. $J$ Biol Chem 267: 16,266-16,273, 1992.
70. Saltiel AR, Fox JA, Sherline P and Cuatrecasas P, Insulin-stimulated hydrolysis of a novel glycolipid generates modulators of cAMP phosphodiesterase. Science 233: 967-972, 1986.

71. Saltiel AR and Cuatrecasas P. Insulin stimulates the generation from hepatic plasma membranes of modulators derived from an inositol glycolipid. Proc Natl Acad Sci USA 83: 5793-5797, 1986.

72. Panten U, Schwanstecher $M$ and Schwanstecher $C$, Pancreatic and extrapancreatic sulfonylurea receptors. Horm Metab Res 24: 549-554, 1992.

73. Feldman JM and Lebovitz HE, An insulin dependent effect of chronic tolbutamide administration on the skeletal muscle carbohydrate transport system. Diabetes 18: 84-95, 1969.

74. Zinman B and Ogilvie RI, The acute effects of tolbutamide on forearm metabolism. $J$ Clin Endocrinol Metab 35: 299-306, 1972.

75. Bak JF, Schmitz O, Schwartz Sorensen N and Pedersen $O$. Postreceptor effects of sulfonylurea on skeletal muscle glycogen synthase activity in type II diabetic patients. Diabetes 38: 1343-1348, 1989.

76. Feldman JM and Lebovitz HE, Appraisal of the extrapancreatic actions of sulfonylureas. Arch Intern Med 123: 314-322, 1977. 